\title{
ペンタシアノコバルト(II)酸錯体を用いたカルコン類 の接触還元によるジヒドロダイマーの生成
}

(1980 年 2 月 5 日受理)

森岡元信・竹内 豊・水野英雄・鈴木盛夫*

\section{1 緒言}

$\alpha, \beta$-不飽和カルボニル化合物の二量化反応について，熱反応， 電気化学反応, 光化学反応の立場から多くの研究が行なわれてき た。この系列の化合物からは反応の違いによって骨格の異なる二 量体が得られる可能性があり，反応の選択性に興味がもたれる。 カルコンの二量化についてはつぎのような研究がある。硫酸ク 口ム(II)打よび硫酸バナジウム(II)による還元二量化 ${ }^{1)}$ ，酢酸中 における亜鉛末での還元二量化2)，少量の塩化コバルト存在下で

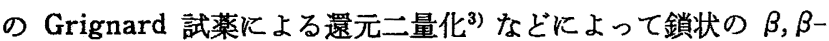
ジヒドロダイマー 2 種類の生成することが報告されている。また， 酸性条件下でアルコール-水系溶媒における電解還元によっても 2 種類の $\beta, \beta$-ジヒドロダイマーのうちの高融点異性体が得られ ている4)。Zuman らは緩衝溶液中, 滴下水銀電極に打けるカルコ ンの電極過程を研究しだ)。上田らはドデカカルボニル三鉄を用 いる $[2+3]$ シクロ付加反応によってシクロペンテン誘導体を得

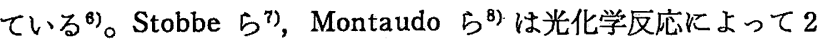
種類のシクロブタン誘導体が生成することを報告している。

著者らはカルコン類のペンタシアノコバルト（II）酸錯体を用い る接触還元を行なった。均一反応にするため $t$ ーブチルアルコー ル一水を溶媒とし反応を行ならと, カルコンからはジヒドロダイ マー [A] が得られ、アルカリの添加により収率はいちじるしく 向上した。 $[A]$ はシクロペンタノール誘導体 $[6]$ であり, 以前 にHarries ${ }^{2)}$, Conant ら ${ }^{1)}$ によって $\beta, \beta$-ジヒドロダイマー $(1,6-$ ジケトン）として誤って報告されていたものの 1 種と同一物であ った。2 種類のカルコン誘導体からあシクロペンタノール構造の ジヒドロダイマーが得られた。これらの構造および生成について 若干の知見を得たので報告する。

* 静岡大学工学部工業化学科, 432 浜松市城北

1) J. B. Conant, H. B. Cutter, J. Am. Chem. Soc., 48, 1016(1926).

2) C. Harries, Liebig's Ann. Chem., 296, 326(1897).

3) M.S. Kharasch, D. C. Sayles, J. Am. Chem. Soc., 64, 2972(1942).

4) R. Pasternak, Helv. Chim. Acta, 31, 753(1948).

5) A. Ryvolová-Kejharová, P. Zuman, J. Electroanal. Chem., 21, 197(1969).

6）上田龍雄，中西三郎，大过吉男，日本化学会第 38 秋季年会 講演予稿集，II， p. 309(1978).

7) H. Stobbe, K. Bremer, J. Prakt. Chem., 124, 1(1929).

8) G. Montaudo, S. Caccamese, J. Org. Chem., 38, 710 (1973).

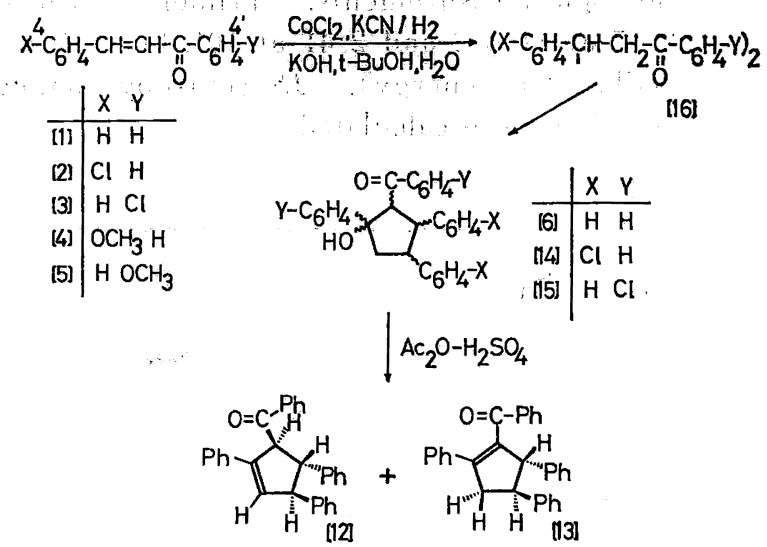

Fig. 1

\section{2 実 験 方 法}

\section{1 測 定}

IR スペクトルは日本分光 IRA-1 型を使用し， $\mathrm{KBr}$ 錠剂法で 測定した。NMR スペクトルは日立高分解能 NMR スペクトロメ ーター R-24 型を用いて，クロロホルムーdを溶媒として测定し， TMS を内部標準とした $\delta$ 值 (ppm) で示した。MS スペクトルは 日立質量分析計 RMU-7 M 型で測定した。UV スペクトルの测 定には日立 124 型ダブルビーム分光光度計を使用した。記載した 融点の測定值には温度計の補正はされていない。

\section{2 試薬}

試薬は市肘特級品を使用した。水素ガスはボンへ入りのものを そのまま使用した。

\section{3 還元試料の合成}

文献の方法にしたがって合成し, 融点, NMR によって確認し た。

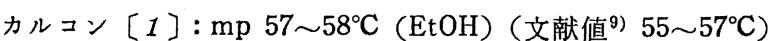

4 -クロロカルコン [2]: $\mathrm{mp} 113 \sim 114^{\circ} \mathrm{C}(\mathrm{EtOH})$ (文献值 ${ }^{10}$ ) $113 \sim 114^{\circ} \mathrm{C}$ )

$4^{\prime}$ ークロロカルコン [3]: $\mathrm{mp} 97 \sim 98^{\circ} \mathrm{C}(\mathrm{EtOH})$ (文献值 ${ }^{11)}$ $101^{\circ} \mathrm{C}$ )

9) E.P. Kohler, M. M. Chadwell, "Organic Syntheses", Coll. Vol. I, p.78(1948).

10) L. C. Raiford, H. L. Davis, J. Am. Chem. Soc., 50, 161(1928).

11) W. Dilthey, J. Prakt. Chem., 101, 177(1921). 
4-メトキシカルョン [4]: $\mathrm{mp} 75 \sim 76^{\circ} \mathrm{C}(\mathrm{EtOH})$ (文献値 ${ }^{12}$ ) $79^{\circ} \mathrm{C}$ )

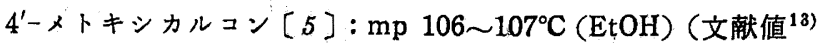
$107^{\circ} \mathrm{C}$ )

\section{4 還元方法}

装固はふりまぜ式接触還元装置を使用した。反応容器は側管付 滴弪漏斗を 2 個付けた $1 l$ の三つロフラスコを使った。塩化コハ ルト六水和物 $1.19 \mathrm{~g}(5 \mathrm{mmol}) を 100 \mathrm{ml}$ の水に溶かし三つロフラ スコに入れ，滴下漏斗の一つにはシアン化カリウム $1.66 \mathrm{~g}(25.5$ $\mathrm{mmol}$ ) と水酸化カリウムを $50 \mathrm{ml}$ の水に溶かして入れ，他の滴 下漏斗に試料 $5 \mathrm{mmol}$ を $150 \mathrm{ml}$ の $t$-ブチルアルコールまたは メタノールに溶かし入れた。三つロフラスコ，滴下漏斗にそれぞ れ氷素ガスを通して酸素を除いた。つぎに反応装置内を脱気し水 素ガスで十分置換したのち反応装置とガスビニレットを接続し た。シアッ化カリウムと水酸化カリウムの混合水溶液を塩化コバ ルト水溶液に加光，水素ガス中で 1 時間ふりまぜを行ない，十分 水素を吸収させた。

つぎに試料溶液をフラスコに加え，さらに水素下で 8 時間ふり まぜを行なった。この段階で出発原料は消失した。反応溶液はへ。 ンタシアノコバルト（II）酸錯体を調製した段階では緑色となっ た。水素ガスを吸収させると薄い黄緑色に変わり, 試料溶液を加 えるとただちに暗赤色の均一溶液になった。反応が進行するとし だい結晶が析出した。

\section{5 生成物の分離および同定}

反応終了後, 析出した不溶珄結晶を汇取した。汇液を約半量に なるまで娍圧濃縮し，エーテル抽出を行ない，さらに粗結晶を得 た。粗生成物をエタノールから分別再結晶法により分離, 精製し た。二量体として $[1],[2],[3]$ からそれぞれ $[6],[14],[15]$ が得られた。

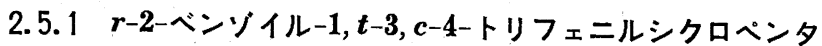
ノール $[\boldsymbol{G}](=[\boldsymbol{A}])$ : 無色結晶 (EtOH), mp 196 197 ${ }^{\circ} \mathrm{C}_{\circ}$

IR $: \nu_{\mathrm{CO}} 1643 \mathrm{~cm}^{-1}, \nu_{\mathrm{OH}} 3484 \mathrm{~cm}^{-1}$

NMR : 2. 4〜 4.7 (シクロペンタン環, $5 \mathrm{H}$ ), 5.16 (s, OH, $1 \mathrm{H}$ ), $6.9 \sim 7.7(\mathrm{~m}$, ベンゼン環, $20 \mathrm{H}$ )

MS : m/e $418\left(\mathrm{M}^{+}, \mathrm{C}_{30} \mathrm{H}_{28} \mathrm{O}_{2}^{+}\right), 400\left(\mathrm{M}^{+}-\mathrm{H}_{2} \mathrm{O}\right), 209\left(\mathrm{C}_{6} \mathrm{H}_{5}-\right.$ $\left.\mathrm{CH}=\mathrm{CH}-\mathrm{C}\left(\mathrm{C}_{6} \mathrm{H}_{5}\right)=\mathrm{OH}^{+}\right)$

分析値 C $85.95 \%, \mathrm{H} 6.26 \%$

$\mathrm{C}_{30} \mathrm{H}_{26} \mathrm{O}_{2}$ としての計算値 C $86.09 \%, \mathrm{H} 6.26 \%$

ベンゼンの凝固点降下法による分子量 : 465

$\mathrm{UV}(\mathrm{MeOH}): \lambda_{\max } 248 \mathrm{~nm}(\varepsilon=8800)$

[6]の脱水反応: [6] $200 \mathrm{mg}$ を無水酢酸 $25 \mathrm{ml}$ に加熱溶解 させ, 室温まで冷却後濃硫酸を 1 滴加えた。室温で 40 分放置後 氷水に注いだ。よくかきまぜたのち一夜放置した。析出した生成 物を沪取し，PLC で脱水生成物として〔12]を $129 \mathrm{mg}$ (収率 $64.5 \%$ ) と〔13]を $10 \mathrm{mg}$ (収率 $5 \%$ ) を分取した。

$c-5$-ベンソイイル-1, r-3, t-4-トリフェニルシクロペンテン [12]: 無色結晶 (EtOH), mp 177 $178^{\circ} \mathrm{C}$ 。

IR $: \nu_{\mathrm{CO}} 1670 \mathrm{~cm}^{-1}$

NMR : $\delta 3.42\left(\mathrm{t},-\mathrm{CH}\left(\mathrm{COC}_{6} \mathrm{H}_{5}\right)-\mathrm{CH}\left(\mathrm{C}_{6} \mathrm{H}_{5}\right)-, \quad 1 \mathrm{H}, J_{3,4}=6\right.$

12) T. Tasaki, Chem. Zentr., 1927, 1949.

13) H. Staudinger, N. Kon, Liebig's Ann. Chem., 384, 123(1912).
$\left.\mathrm{Hz}, J_{4,5}=6 \mathrm{~Hz}\right), 4.24\left(\mathrm{~m},=\mathrm{CH}-\mathrm{CH}\left(\mathrm{C}_{6} \mathrm{H}_{5}\right)-, 1 \mathrm{H}, J_{2,3}=2 . £\right.$ $\left.\mathrm{Hz}, J_{3,4}=6 \mathrm{~Hz}, J_{3,5}=2 \mathrm{~Hz}\right), 5.18\left(\mathrm{~m},-\mathrm{CH}\left(\mathrm{COC}_{6} \mathrm{H}_{5}\right)-, 1 \mathrm{H}\right.$, $\left.J_{4,5}=6 \mathrm{~Hz}, J_{3,5}=2 \mathrm{~Hz}, J_{2,5}=1.5 \mathrm{~Hz}\right), 6.48(\mathrm{~m},=\mathrm{CH}-, 1 \mathrm{H}$, $\left.J_{2,3}=2.5 \mathrm{~Hz}, J_{2,5}=1.5 \mathrm{~Hz}\right), 7.0 \sim 7.8(\mathrm{~m}$, ヘンンビ環, $20 \mathrm{H}$ ) MS : $m / e 400\left(\mathrm{M}^{+}, \mathrm{C}_{30} \mathrm{H}_{24} \mathrm{O}^{+}\right)$

分析値 C $90.03 \%$, H $6.04 \%$

$\mathrm{C}_{30} \mathrm{H}_{24} \mathrm{O}$ としての計算值 C $89.97 \%, \mathrm{H} 6.04 \%$

trans-2 ヘンソイル-1, 3, 4-トリフェニルシクロヘンテン

[13]：無色結晶 (EtOH), $\mathrm{mp} 121.5 \sim 122.5^{\circ} \mathrm{C}^{14)}$ 。

IR $: \nu_{\mathrm{CO}} 1628 \mathrm{~cm}^{-1}$

NMR : 3.0 3.94, 4.51〜4.75 (m, シクロベンテン環, $4 \mathrm{H}$ ), $6.67 \sim 7.81(\mathrm{~m}$, ペンゼン環, $20 \mathrm{H})$

MS : m/e $400\left(\mathrm{M}^{+}, \mathrm{C}_{30} \mathrm{H}_{24}^{\circ} \mathrm{O}^{+}\right)$

分析值 C $89.94 \%, \mathrm{H} 6.01 \%$

$\mathrm{C}_{30} \mathrm{H}_{24} \mathrm{O}$ としての計算值 C $89.97 \%, \mathrm{H} 6.04 \%$

2.5.2 1-フェニル-2-ベンッイル-3-4-ビス(4-クロロフェニ ル)シクロペンタノール [14]：無色結晶 $(\mathrm{EtOH}), \quad \operatorname{mp~171〜~}$ $172^{\circ} \mathrm{C}_{\text {。 }}$

IR $: \nu_{\mathrm{CO}} 1664 \mathrm{~cm}^{-1}, \nu_{\mathrm{OH}} 3472 \mathrm{~cm}^{-1}$

NMR : 2.4 4. 7 (m, シクロペンタン環, $5 \mathrm{H}$ ), $5.04(\mathrm{~s}, \mathrm{OH}$, $1 \mathrm{H}), 6.9 \sim 7.6(\mathrm{~m}$, ベンゼン環, $18 \mathrm{H})$

MS : m/e $486\left(\mathrm{M}^{+}, \mathrm{C}_{30} \mathrm{H}_{24}{ }^{35} \mathrm{Cl}_{2} \mathrm{O}_{2}{ }^{+}\right), \quad 468\left(\mathrm{M}^{+}-\mathrm{H}_{2} \mathrm{O}\right), \quad 245$ $\left({ }^{37} \mathrm{Cl}-\mathrm{C}_{6} \mathrm{H}_{4}-\mathrm{CH}=\mathrm{CH}-\mathrm{C}\left(\mathrm{C}_{6} \mathrm{H}_{5}\right)=\mathrm{OH}^{+}\right), \quad 243\left({ }^{85} \mathrm{Cl}-\mathrm{C}_{8} \mathrm{H}_{4}-\mathrm{CH}=\mathrm{CH}-\mathrm{C}\right.$ $\left.\left(\mathrm{C}_{6} \mathrm{H}_{5}\right)=\mathrm{OH}^{+}\right)$

分析值 C $73.62 \%, \mathrm{H} 4.98 \%$

$\mathrm{C}_{30} \mathrm{H}_{24} \mathrm{Cl}_{2} \mathrm{O}_{2}$ としての計算值 C $73.93 \% ， \mathrm{H} 4.96 \%$

2.5.3 1-(4-クロロフェニル)-2-(4-クロロベンソイル)-3,4ジフェニルシクロペンタノール [15]：無色結晶(EtOH), mp 173 $\sim 175^{\circ} \mathrm{C}_{\text {。 }}$

IR $: \nu_{\mathrm{CO}} 1641 \mathrm{~cm}^{-1}, \nu_{\mathrm{OH}} 3446 \mathrm{~cm}^{-1}$

$\mathrm{NMR}: \delta 2.4 \sim 4.7(m$, シクロペンタン環, $5 \mathrm{H}), 5.22(\mathrm{~s}, \mathrm{OH}$, $1 \mathrm{H}), 7.0 \sim 7.5(\mathrm{~m}$, ベンゼン環, $18 \mathrm{H}$ )

MS : m/e $486\left(\mathrm{M}_{1}^{+}, \mathrm{C}_{30} \mathrm{H}_{24}{ }^{35} \mathrm{Cl}_{2} \mathrm{O}_{2}{ }^{+}\right), 488\left(\mathrm{M}_{2}{ }^{+}, \mathrm{C}_{30} \mathrm{H}_{24}{ }^{35} \mathrm{Cl}\right.$ $\left.{ }^{37} \mathrm{ClO}_{2}{ }^{+}\right), 468\left(\mathrm{M}_{1}{ }^{+}-\mathrm{H}_{2} \mathrm{O}\right), 470\left(\mathrm{M}_{2}{ }^{+}-\mathrm{H}_{2} \mathrm{O}\right), 472\left(\mathrm{M}_{3}{ }^{+}\left(\mathrm{C}_{30} \mathrm{H}_{24}\right.\right.$ $\left.\left.{ }^{37} \mathrm{Cl}_{2} \mathrm{O}_{2}{ }^{+}\right)-\mathrm{H}_{2} \mathrm{O}\right), \quad 243\left(\mathrm{C}_{6} \mathrm{H}_{5}-\mathrm{CH}=\mathrm{CH}-\mathrm{C}\left(\mathrm{C}_{6} \mathrm{H}_{4}{ }^{35} \mathrm{Cl}\right)=\mathrm{OH}^{+}\right), \quad 245$ $\left(\mathrm{C}_{6} \mathrm{H}_{5}-\mathrm{CH}=\mathrm{CH}-\mathrm{C}\left(\mathrm{C}_{6} \mathrm{H}_{4}{ }^{37} \mathrm{Cl}\right)=\mathrm{OH}^{+}\right)$

分析值 C $74.23 \%, \mathrm{H} 5.01 \%$

$\mathrm{C}_{30} \mathrm{H}_{24} \mathrm{Cl}_{2} \mathrm{O}_{2}$ としての計算值 C $73.93 \%, \mathrm{H} 4.96 \%$

\section{3 結果之考察}

カルコン [1]をベンゼンに溶かし，ペタシアノコバルト（II） 酸錯体水溶液を用いて接触還元を行ならと，不均一相となり [1] の二重結合が水素化されたジヒドロカルコンが低収率で得られ た。均一反応とするため $50 \%$ メタノール中で反応を行ない， タノールから再結晶をくり返すと，[A]が低収率で得られた。 [A]の収率は $t$-ブチルアルコール一水を溶媒とし，アルカリを 添加するといちじるしく向上した（表 1 ）。

[A]の MS スペクトルには $m / e 418$ に親ピークがあり $\mathrm{C}_{30} \mathrm{H}_{26} \mathrm{O}_{2}$ に相当する。 $m / e 400$ には脱水によるピークが認めら

14) Conant らはカルコンからの $\beta, \beta$-ジヒドロダイマーの 1 種 をナトリウムエトキシドと加熱して $\mathrm{mp} 123^{\circ} \mathrm{C}$ の物質を 得, 2-ベンゾイル-1, 3, 4-トリフェニルシクロペンテンで あると報告している(文献 1)). 
Table 1 Dimerization of chalcone [1] by catalytic hydrogenation with pentacyanocobaltate(II)

\begin{tabular}{lcccr} 
Solvent & $\begin{array}{c}\mathrm{CoCl}_{2} \cdot 6 \mathrm{H}_{2} \mathrm{O} \\
(\mathrm{mmol})\end{array}$ & $\begin{array}{c}\mathrm{KCN} \\
(\mathrm{mmol})\end{array}$ & $\begin{array}{c}\mathrm{KOH} \\
(\mathrm{mmol})\end{array}$ & $\begin{array}{c}\text { Yield of } \\
{[6]}\end{array}$ \\
\hline $\mathrm{MeOH}-\mathrm{H}_{2} \mathrm{O}$ & 30 & 153 & 0 & 1 \\
$t-\mathrm{BuOH}-\mathrm{H}_{2} \mathrm{O}$ & 30 & 153 & 0 & 30 \\
$t-\mathrm{BuOH}-\mathrm{H}_{2} \mathrm{O}$ & 5 & 25.5 & 0 & 5 \\
$t-\mathrm{BuOH}-\mathrm{H}_{2} \mathrm{O}$ & 5 & 25.5 & 5 & 35 \\
$t-\mathrm{BuOH}-\mathrm{H}_{2} \mathrm{O}$ & 5 & 25.5 & 25 & 48
\end{tabular}

Equimolar amount of the substrate was used. $\mathrm{H}_{2} \mathrm{O} 150 \mathrm{ml}+$ alcohol $150 \mathrm{ml}$ were used.

$\mathrm{H}_{2} 1 \mathrm{~atm}$, Temp. $25^{\circ} \mathrm{C}$, Time $8 \mathrm{~h}$.<smiles>O=C(c1ccccc1)C1C(c2ccccc2)CC(O)(c2ccccc2)C1c1ccccc1</smiles>

[6]
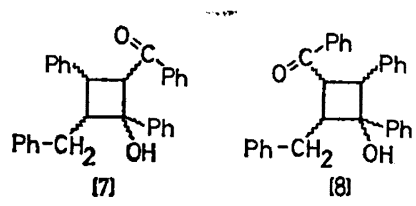

[8]

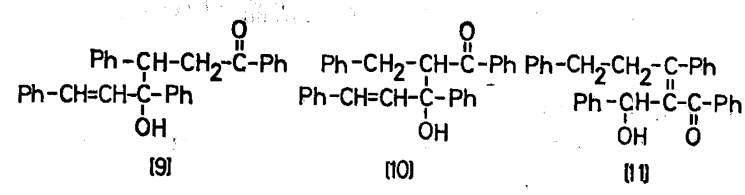

Fig. 2

れた。 $\mathrm{CH}$ 分析の結果も分子式とよく一致している。IR スペクト ルはカルボニル基とヒドロキシル基の存在を示した。この化合物 は種々の溶媒に対する溶解度が小さいため明膫な NMR スペクト ルが得られず，詳細な解析はできなかったが，ヒドロキシル基 1 個の存在を示した。また，〔A]のUV スペクトルには $\alpha, \beta$-不 飽和ヶトンに相当する吸収は存在しない。

以上から， $\beta, \beta$-ジヒドロダイマー $[16](X=Y=H)$ や, ジヒ ドロカルコンとカルコンとの Michael 付加化合物 ${ }^{15)}$ に相当しな いことがわかる。 $\mathrm{C}_{30} \mathrm{H}_{26} \mathrm{O}_{2}$ の分子式をるち， ヒドロキシル基 1 個とカルボニル基とを有する構造式としては [6], [7],[8](そ

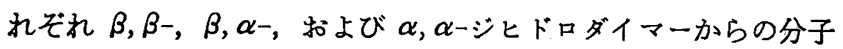
内アルドール縮合生成物)，[9],[10], [11] が考兄られ。[A] の NMR スペクトルにはビニル水素が認められないので [9], [10]は除かれる。

また, UV スペクトルの結果から[11]も除かれる。ジヒドロ ダイマーの構造が [6], [7], [8] のいずれかであるかを確かめ るため脱水反応を行なった。脱水生成物としてビニル水素を有す る〔12]と有しない[13]の 2 種類が単離された。[7],[8]に 脱水反応を行なってもビニル水素をるつ物質は生成しないはずで あるが，〔6]の構造からは可能である。

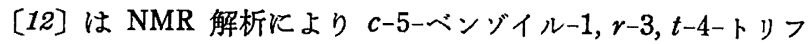
エニルシクロペンテン22) と同定されたので, $[A]=[6]$ は $r-2-$

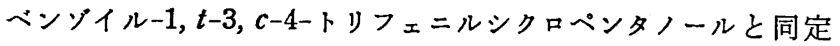
されだ)。Conant らりはカルコンをクロム(II) またはバナジウ

15) L. Mordenti, J. J. Brunet, P. Caubere, J. Org. Chem., 44, 2203(1979).

16） 2 位のベンソイルの $\nu_{\mathrm{CO}}$ は $1643 \mathrm{~cm}^{-1}$ と低波数にシフト しており， 1 位のヒドロキシル基と水素結合していること が考えられる. したがって 1 位の $\mathrm{OH}$ と 2 位のベンゾイル 基はシスの関係と想像される。
Table 2 Substituent effect on dimerization of $\mathrm{X}_{-}-\mathrm{C}_{6} \mathrm{H}_{4}-$ $\mathrm{CH}=\mathrm{CH}-\mathrm{CO}-\mathrm{C}_{6} \mathrm{H}_{4}-\mathrm{Y}$

\begin{tabular}{llrrr}
\multicolumn{1}{c}{$\mathrm{X}$} & \multicolumn{1}{c}{$\mathrm{Y}$} & \multicolumn{2}{c}{ Yield of } \\
$\operatorname{dimer}(\%)$ & $\begin{array}{r}\text { Recovery } \\
(\%)\end{array}$ \\
\hline $\mathrm{H}$ & $\mathrm{H}$ & {$[6] 35$} & - \\
$p-\mathrm{Cl}$ & $\mathrm{H}$ & {$[14] 50$} & - \\
$\mathrm{H}$ & $p-\mathrm{Cl}$ & {$[15] 30$} & - \\
$p-\mathrm{OCH}_{8}$ & $\mathrm{H}$ & 0 & 70 \\
$\mathrm{H}$ & $p-\mathrm{OCH}_{3}$ & & 0 & 74
\end{tabular}

Substrate $5 \mathrm{mmol}, \mathrm{CoCl}_{2} \cdot 6 \mathrm{H}_{2} \mathrm{O} 5 \mathrm{mmol}, \mathrm{KCN} 25.5 \mathrm{mmol}$, $\mathrm{KOH} 5 \mathrm{mmol}, \mathrm{H}_{2} \mathrm{O} 150 \mathrm{ml}+t-\mathrm{BuOH} 150 \mathrm{ml}, \mathrm{H}_{2} 1 \mathrm{~atm}$, Temp. $25^{\circ} \mathrm{C}$

ム(II) と処理してジヒドロダイマー 2 種類を得 $(\mathrm{mp} \mathrm{266} \mathrm{C}$ およ び $\mathrm{mp} 194^{\circ} \mathrm{C}$ ), 鎖状の $\beta, \beta$-ジとドロダイマー構造を提案してい るが，追試を行なって得られた低融点化合物は混融試験, IR 㧊よ び NMR スペクトルから〔6]と同一物であった。

4 種のカルコン誘導体についての実験結果を表 2 に示した。4クロロカルコンおよび 4'-クロロカルコンから, IR および NMR スペクトルが [6]と同様のパターンを示すダイマーが得られた。 4-メトキシー および 4'ーメトキシカルコンからはダイマーは得ら れず，出発物質を高収率で回収した。

ペンタシアノコバルト(II)を触媒とする水素化の機構について

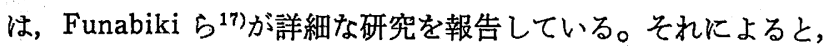
水素がヒドリドとして移動するオルガノコバルト錯体を含む機構 と水素がラジカルとして移動する機構が，基質によって一方また は並行して進行するとなっている。また, Hanzlík ら ${ }^{18)}$, Lim $ら^{19)}, \mathrm{Kim} 5^{20)}$ は強アルカリ性に拈いては $\left[\mathrm{CoIIH}(\mathrm{CN})_{5}\right]^{3-}$ から $\left[\mathrm{CoI}(\mathrm{CN})_{5}\right]^{4-を}$ を生じ，これが一電子還元剂として反応するこ とを報告している。 $\alpha, \beta$-不飽和ヶトンから一電子還元剤や電気 化学的還元法によって生成する二量体は $\beta, \beta$-ジヒドロダイマー が主である報告が大部分である21)。これらを参考にすると，[6] の型の二量体は $\left[\mathrm{CoI}(\mathrm{CN})_{5}\right]^{4-}$ による電子移動を含む反応で生

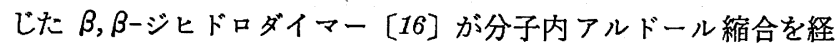
て生成したものと推定される。

終りにあたって，ご討諭いただいた松島良華博士，本研究に協 カしてくださった勝川 博氏，三原敦夫氏に感謝いたします。

(1979 年 10 月, 第 10 回中部化学関係学協会支部連合秋季大会 講演)

17) T. Funabiki, K. Tarama, Bull. Chem. Soc. Jpn., 44, 945(1971) ; T. Funabiki, M. Matsumoto, K. Tarama, ibid., 45, 2723(1972) ; T. Funabiki, M. Mohri, K. Tarama, J. Chem. Soc. Dalton Trans., 1973, 1813.

18) J. Hanzlík, A. A. Vlček, Chem. Commun., 1969, 47; A. A. Vlček, J. Hanzlík, Inorg. Chem., 6, 2053(1967); J. Hanzlík, A. A. Vlček, ibid., 8, 669(1969).

19) H.S. Lim, F. C. Anson, Inorg. Chem., 10, 103(1971).

20) J.-Y. Kim, T. Kwan, Chem. Pharm. Bull., 18, 1040 (1970).

21) K. W. Bowers, R. W. Giese, J. Grimshaw, H. O. House, N. H. Kolodny, K. Kronberger, D. K. Doe, J. Am. Chem. Soc., 92, 2783(1970).

22）結合定数から 3,4 位の水素間， 4, 5 位の水素間の二面体 角は約 $30^{\circ}$, 約 $30^{\circ}$ または約 $130^{\circ}$, 約 $130^{\circ}$ と推定される. $30^{\circ}(3,4-c i s-4,5-c i s-)$ とすると 4 位の炭素がシクロペン テン環平面より大きくずれ，ひずみが生じる。しかし $130^{\circ}$ (3, 4-trans-4, 5-trans-) ならば可能と推定される. 


\section{Formation of Dihydrodimers by Catalytic Hydrogenation of Chalcones with Pentacyanocobaltate(II) \\ Motonobu Morioka, Yutaka TAKEUCHI, Hideo Mizuno and Morio Suzuki \\ Department of Industrial Chemistry, Faculty of Engineering,. Shizuoka \\ University; Johoku, Hamamatsu-shi 432 Japan}

The catalytic hydrogenation of chalcones with pentacyanocobaltate(II) afforded $r$-2-benzoyl$1, t-3, c-4$-triphenylcyclopentanols, dimeric products from chalcones. The use of $50 \%$ aqueous $t$-butyl alcohol as a solvent and the addition of potassium hydroxide resulted in the increase of the dimeric product yields. The replacement of hydrogen at 4-position of chalcone with chlorine increased the yield of the corresponding dimeric product whereas the methoxy groupe at 4 - or $4^{\prime}$-position of chalcone entirely suppressed the reaction. 